SOIL CLAY MODIFICATION WITH SPERMINE AND ITS EFFECT ON THE BEHAVIOR OF THE HERBICIDE FLUOMETURON

\author{
B. Gámiz, R. Celis*, M.C. Hermosín, and J. Cornejo \\ Instituto de Recursos Naturales y Agrobiología de Sevilla (IRNAS), CSIC, Avenida Reina \\ Mercedes 10, P.O. Box 1052, 41080 Sevilla, Spain
}

* Corresponding Author: Dr. Rafael Celis, Address: Instituto de Recursos Naturales y Agrobiología de Sevilla (IRNAS), CSIC, Avenida Reina Mercedes 10, P.O. Box 1052, 41080 Sevilla, Spain, Phone: +34 954624711, Fax: +34 954624002, E-mail: rcelis@irnase.csic.es

Acknowledgments: This work has been financed by the Spanish Ministry of Science and Innovation (Project AGL2008-04031-C02-01) and Junta de Andalucía (Project P07-AGR03077 and Research Group AGR-264), and cofinanced with FEDER-FSE funds. The authors wish to thank M. Real for his help with the soil characterization. B. Gámiz also thanks Junta de Andalucía for her FPI fellowship. 


\section{SOIL CLAY MODIFICATION WITH SPERMINE AND ITS EFFECT ON THE}

\section{BEHAVIOR OF THE HERBICIDE FLUOMETURON}

\section{ABSTRACT}

Research on organoclays as sorbents of pesticides has shown the usefulness of these materials both as soil amendments and as pesticide supports, to prolong the efficacy and reduce the environmental impact of soil-applied pesticides. Organoclays can also be formed in situ by direct modification of smectite-rich soil clays through treatment with appropriate organic cations. In this work, laboratory experiments were conducted to investigate the effect of the addition to soil of a natural organic cation, spermine, on sorption (batch equilibration procedure), persistence (incubation experiments) and leaching (column experiments) of the herbicide fluometuron. Four soils differing in their clay contents and mineralogy were used. A seven-fold increase in the fluometuron sorption distribution coefficient, $K_{\mathrm{d}}$, by the presence of spermine was observed for a clay soil rich in smectites (soil 1), whereas the effect on fluometuron sorption was negligible for a soil with similar clay texture but lacking smectites (soil 4) and for a loamy sand soil with very low content in smectites (soil 3). A sandy loam soil (soil 2) with moderate smectite content had an intermediate behavior. The increase in fluometuron sorption was thus related to the smectite content of the soils, strongly indicating that reaction of spermine with soil smectites formed in situ an organoclay complex with high affinity for fluometuron. The simultaneous application of fluometuron and spermine to the smectite-rich soil retarded the leaching of the herbicide but, at the same time, increased the total amount of fluometuron leached from 25 to 52\%. This was attributed to the fact that spermine, apart from increasing sorption, also prolonged the persistence of fluometuron in the smectite-rich soil. In contrast, the presence of spermine had no effect on the leaching pattern of fluometuron in the clay soil lacking smectites. The results indicated that the application of 
suitable organic cations to smectitic soils can be a useful strategy to control pesticide retention and persistence in the soil environment.

\section{INTRODUCTION}

The widespread use of pesticides in modern agricultural production and other activities has resulted in increasing levels of pesticide residues in natural ecosystems, thus becoming an important environmental problem. One main problem of pesticide use relates to the large transport losses that usually affect pesticides applied to agricultural land, which cause offsite movement of the pesticide and diffuse contamination of soil and water systems. In this context, there is a need to develop efficient strategies to prevent and mitigate soil and water contamination by pesticides, and particularly to reduce pesticide mobility in the environment (Hapeman et al., 2003).

Organoclays, that is, natural clay minerals with their original inorganic exchangeable cations replaced with organic cations, have been proven to be very good sorbents for different classes of pesticides and, accordingly, have been proposed to prevent and remediate environmental contamination by pesticides (Hermosín et al., 1992; Brixie and Boyd, 1994; Prost and Yaron, 2001; Cornejo et al., 2008). Research on organoclays as sorbents of pesticides has shown the usefulness of these materials both as soil amendments and as pesticide supports, to prolong the efficacy of soil-applied pesticides and to reduce the large transport losses that usually affect pesticides applied in an immediately available form (Carrizosa et al., 2000; El-Nahhal et al., 2001; Trigo et al., 2009; Undabeytia et al., 2010; Gámiz et al., 2010). An alternative approach is the in situ formation of organoclay complexes by direct modification of smectite-rich soil clays through treatment with appropriate organic cations. For instance, it has been shown that the addition of alkylammonium cations to soils can enhance the retention of organic pollutants and reduce their leaching through the soil 
profile (Boyd et al., 1988; Lee et al., 1989; Sánchez et al., 2003; Rodríguez-Cruz et al., 2007). Nevertheless, the existing information on the effects of specific organic cations as soil modifiers on pesticide behavior is still scarce. This is particularly true for naturally-occurring organic cations, since research on organoclays as sorbents of pesticides has focused on synthetic, alkylammonium-type cations of the general form $\left[\left(\mathrm{CH}_{3}\right)_{3} \mathrm{NR}\right]^{+}$or $\left[\left(\mathrm{CH}_{3}\right)_{2} \mathrm{NR}_{2}\right]^{+}$, where $\mathrm{R}$ is an aromatic or aliphatic hydrocarbon (Cruz-Guzmán et al., 2004). The use of natural organic cations for clay mineral modification has been stressed as particularly interesting to reduce concern about incorporation of these materials into soil and aquatic environments for practical applications (Cruz-Guzmán et al., 2004; Celis et al., 2007).

Fluometuron (Figure 1) is a pre- and early post-emergence phenylurea herbicide widely used for controlling annual grasses and broad-leaved weeds mainly in cotton and olive groves at 1-2 $\mathrm{kg} \mathrm{ha}^{-1}$. It has a molecular weight of $232.2 \mathrm{~g} \mathrm{~mol}^{-1}$ and a water solubility of $105 \mathrm{mg} \mathrm{L}^{-1}$ at $20^{\circ} \mathrm{C}$ (Worthing and Hance, 1991). Fluometuron sorption in soil has been related primarily to the soil organic matter content (Savage and Wauchope, 1974; Mueller et al., 1992). In Southern Spain and other regions of the world, cotton and olive crops represent high-risk scenarios of ground and surface water contamination by herbicides; soil properties and climatic conditions favor herbicide leaching and runoff processes and it is therefore important to develop strategies directed to optimize herbicide efficacy and prevent water pollution (Mueller et al., 1992; Trigo et al., 2009; Gámiz et al., 2010, Locke et al., 2011).

In previous laboratory experiments, we found that the modification of reference smectites (SWy-2 and SAz-1) with the naturally-occurring organic cation spermine (Figure 1) resulted in organoclays with very high affinity for phenylurea herbicides, including fluometuron (Celis et al., 2007; Gámiz et al. 2010). Spermine-exchanged reference smectites were efficient both as soil amendments, to increase the soil retention capacity for such herbicides, and also as herbicide supports, for the development of herbicide slow release formulations (Trigo et al., 
2009; Gámiz et al., 2010). The objective of the present work was to investigate the effects of spermine addition to natural soils on sorption, persistence, and leaching of the herbicide fluometuron, and to relate such effects to the soil clay mineralogy. Our hypothesis was that spermine cations should react with soil smectites, increasing the soil retention capacity and retarding herbicide leaching, that is, a sort of "in situ" slow release formulation could be formed in soils by the simultaneous application of the herbicide and spermine. Four soils with different clay contents and mineralogy were selected, characterized, and the influence of spermine on fluometuron behavior (sorption, persistence, and leaching) in the soils assessed by batch sorption, incubation, and column leaching tests.

\section{MATERIALS AND METHODS}

\section{Herbicide, organic cation, and soils}

Pure analytical fluometuron (purity $=99.5 \%$ ) purchased from Sigma-Aldrich (Spain) was used to prepare the external standards for fluometuron analysis and the initial solutions used in the batch sorption experiments. Commercial fluometuron (Dinagam Linz, 50\% suspension concentrate) supplied by Bayer (Spain) was used in the persistence and column leaching experiments.

Spermine (Figure 1) was supplied as a high-purity tetrachloride salt by Sigma-Aldrich (Spain). Spermine is a naturally-occurring polyamine with four $\mathrm{p} K_{\mathrm{a}}$ values which lie in the interval 8-11 (Frassineti et al., 1995). Accordingly, the fully protonated form of spermine is supposed to predominate under acidic, neutral, and slightly basic conditions.

Four agricultural soils from Seville (SW Spain) were used in this study. The soils were selected on the basis of their different clay contents and mineralogy, which resulted in a range of smectite contents in the whole soils. Soil 1 was sampled from a cotton area that had received repeated applications of fluometuron for years as an agricultural practice, although 
the soil sample used in this study contained no detectable background concentration of fluometuron. Soils 2, 3, and 4 were sampled, respectively, from olive-, cereal-, and citrusgrowing plots and had no history of previous applications of fluometuron. All four soils were sampled from the top 0-20 cm layer, air-dried, and sieved ( $2 \mathrm{~mm})$, prior to use.

\section{Soil characterization}

The texture of the soils was determined by the hydrometer method (Klute, 1986). The organic carbon contents were determined by dichromate oxidation, the carbonate contents by the pressure calcimeter method, and the cation exchange capacities (CEC) by the $1 \mathrm{M}$ ammonium acetate method (Jackson, 1975; Sparks, 1996). Soil pH values were measured in 1:2.5 soil:1 $M \mathrm{KCl}$ aqueous suspensions. The variability associated with the measured soil properties was $<10 \%$.

A detailed characterization of the pore size distribution of the soils and of their clay mineralogy was also carried out. The soil pore-size distributions (from 40 to $0.004 \mu \mathrm{m}$ ) were determined by mercury intrusion porosimetry using a Carlo Erba 2000 mercury intrusion porosimeter. A soil core of approximately $1 \mathrm{~g}$ was sampled and dried at $90{ }^{\circ} \mathrm{C}$ for 24 hours before the porosity analysis. A value for the surface tension of mercury of $\gamma=0.48 \mathrm{~N} \mathrm{~m}^{-1}$ and a mercury solid contact angle of $\theta=171.3^{\circ}$ were assumed to use the Washburn (1921) equation for the calculation of the pore size distributions.

Carbonates were removed from the soils by treatment with ammonium acetate/acetic acid buffer $(\mathrm{pH}=5)$ before separating the soil clay $(<2 \mu \mathrm{m})$ fractions by sedimentation for subsequent mineralogical analysis. The amounts of amorphous $\mathrm{Fe}$ and $\mathrm{Al}$ in the soil clays were determined by oxalate-extraction (McKeague and Day, 1966), whereas the phyllosilicate mineralogy was determined by X-ray diffraction analysis on oriented specimens of $\mathrm{Mg}^{2+}$ - and $\mathrm{K}^{+}$-saturated clay samples, solvated with liquid ethylene glycol (EG) and calcined at $550{ }^{\circ} \mathrm{C}$, 
respectively (Brown, 1961). X-ray diffractograms were obtained in a D-5000 diffractometer (Siemens, Stuttgart) using $\mathrm{CuK}_{\alpha}$ radiation.

\section{Sorption experiments}

The effect of spermine on fluometuron sorption by the different soils was determined by the batch equilibration procedure using glass centrifuge tubes and a single herbicide initial concentration $C_{\text {ini }}=1 \mathrm{mg} \mathrm{L}^{-1}$. This concentration was selected for being representative of field concentrations of fluometuron applied at $1-2 \mathrm{~kg} \mathrm{ha}^{-1}$. Triplicate 4 g-soil aliquots were equilibrated by shaking for $24 \mathrm{~h}$ at $20 \pm 2{ }^{\circ} \mathrm{C}$ with $8 \mathrm{~mL}$ of aqueous solutions of fluometuron $\left(1 \mathrm{mg} \mathrm{L}^{-1}\right)$, also containing an amount of spermine tetrahydrochloride corresponding to $0,1,5$, 10, 25 or $100 \%$ of the CEC of the 4 g-soil aliquot. After equilibration, the suspensions were centrifuged and $4 \mathrm{~mL}$ of the supernatant solution was removed, filtered using a glass fiber filter (pore diameter= $0.45 \mu \mathrm{m}$ ), and analyzed by high-performance liquid chromatography (HPLC) to determine the equilibrium concentration, $C_{\mathrm{e}}\left(\mathrm{mg} \mathrm{L}^{-1}\right)$, of fluometuron. The amount of fluometuron sorbed by the soils, $C_{\mathrm{s}}\left(\mathrm{mg} \mathrm{kg}^{-1}\right)$, was calculated from the difference between the initial $\left(C_{\text {ini }}\right)$ and equilibrium $\left(C_{\mathrm{e}}\right)$ solution concentrations. A $1 \mathrm{mg} \mathrm{L}^{-1}$ fluometuron solution without soil was also shaken for $24 \mathrm{~h}$ and served as a control to rule out the possibility that processes other than sorption to the soils contributed to the decrease in the fluometuron solution concentration during the $24 \mathrm{~h}$ equilibration. The percentage of fluometuron sorbed (\% Sorbed) for the initial herbicide concentration of $1 \mathrm{mg} \mathrm{L}^{-1}$ was calculated by using the following formula: \% Sorbed $=\left[\left(C_{\mathrm{ini}}-C_{\mathrm{e}}\right) / C_{\mathrm{ini}}\right] \times 100$, whereas sorption distribution coefficients, $K_{\mathrm{d}}\left(\mathrm{L} \mathrm{kg}^{-1}\right)$ were calculated as $K_{\mathrm{d}}=C_{\mathrm{s}} / C_{\mathrm{e}}$. Previous work reported linear sorption of fluometuron on soils at herbicide concentrations around $1 \mathrm{mg} \mathrm{L}^{-1}$ and that $24 \mathrm{~h}$ was sufficient to reach the soil sorption equilibrium for fluometuron (Rankins et al., 2002). 


\section{Column leaching experiment}

Leaching was studied in $30 \mathrm{~cm}$ length $\mathrm{x} 3.1 \mathrm{~cm}$ internal diameter glass columns filled with $160 \mathrm{~g}(20 \mathrm{~cm}$ ) of soil (soils 1 and 4), following a procedure similar to that described in Gámiz et al. (2010). The soil columns were saturated with deionized water and allowed to drain for $24 \mathrm{~h}$. The calculated pore volume of the columns after saturation was $63 \pm 1 \mathrm{~mL}$ for both soils. Once saturated, $6 \mathrm{~mL}$ of an aqueous solution containing $0.15 \mathrm{mg}$ of commercial fluometuron, active ingredient (a.i.), was applied to the top of triplicate soil columns to give an herbicide application rate of $2 \mathrm{~kg}$ a.i. ha ${ }^{-1}$. The fluometuron solution added also contained the amount of spermine tetrahydrochloride needed to compensate the CEC of the amount of soil (20 g) present in the top $0-2.5 \mathrm{~cm}$ of the column. Daily, $15 \mathrm{~mL}$ of deionized water were added to the top of the columns, the leachates were collected, and the concentration of fluometuron was determined by HPLC. Breakthrough curves (BTCs) of fluometuron in soils 1 and 4 were thus obtained and compared with those obtained with control soil columns treated identically but without spermine addition. At the end of the leaching experiment, the soil columns were extracted with methanol to determine the residual amount of fluometuron (Gámiz et al., 2010). All leaching experiments were conducted in triplicate.

The position of the maximum concentration peaks of the BTCs was compared with the predicted retardation factor $(R F)$ calculated assuming linear, instantaneous, and reversible sorption conditions using the following equation (Rao et al., 1985):

$$
R F=1+(\rho / \theta) K_{\mathrm{d}} \quad \text { Eq. }(1)
$$

In Eq. 1, $\rho$ is the bulk density of the soil column $\left(\mathrm{g} \mathrm{cm}^{-3}\right) ; \theta$ is the soil column volumetric water content $\left(\mathrm{cm}^{3} \mathrm{~cm}^{-3}\right)$ and $K_{\mathrm{d}}\left(\mathrm{L} \mathrm{kg}^{-1}\right)$ is the sorption distribution coefficient for the herbicide in the soil column. The $K_{d}$ values measured in the batch sorption experiments were 
assumed for the calculation of the $R F$ values using Eq. 1. The $R F$ value represents the number of pore volumes at which the maximum concentration of the herbicide is expected to appear in leachates (Flores-Céspedes et al., 2002).

\section{Incubation experiment}

The effect of spermine on fluometuron dissipation in soil 1 was determined by means of an incubation experiment in which a portion of $100 \mathrm{~g}$ of soil was spiked with commercial fluometuron at a rate of $2 \mathrm{mg}$ a.i. $\mathrm{kg}^{-1}$. The aqueous solution of fluometuron $(40 \mathrm{~mL})$ used to spike the soil contained either no spermine or the amount of spermine tetrahydrochloride (3.6 g) needed to compensate $100 \%$ of the CEC of the 100 g-soil aliquot. The spiked soil samples were incubated in glass jars at $20 \pm 2^{\circ} \mathrm{C}$ for 40 days. The moisture content of the soil was maintained at a constant level ( 30\%) throughout the experiment by adding distilled water as necessary. Twice a week, triplicate 3 g-soil aliquots were sampled using a sterilized spatula and frozen immediately until analyzed. Fluometuron residues in the $3 \mathrm{~g}$ soil-aliquots were determined by extraction with $8 \mathrm{~mL}$ of methanol ( $24 \mathrm{~h}$ shaking), followed by centrifugation and analysis of the supernatant by HPLC. Preliminary experiments had shown that this extraction procedure recovered $>95 \%$ of the fluometuron freshly applied to the soils (Gámiz et al., 2010). Differences between the amount of fluometuron added to the soil and the amounts extracted with methanol were assumed to be due to degradation and/or formation of strongly-bound herbicide residues (Albarrán et al., 2003).

\section{Analysis of fluometuron}

Fluometuron was determined by high performance liquid chromatography (HPLC) using a Waters 600E chromatograph coupled to a Waters 996 diode-array detector. Details on the chromatographic conditions used for the analysis can be found in Gámiz et al. (2010). 
Instrumental limit of detection (LOD) was calculated as the lowest observable concentration giving a signal-to-noise $(\mathrm{S} / \mathrm{N})$ ratio of $3: 1$, while instrumental limit of quantification (LOQ) was calculated as the concentration resulting in an S/N ratio of 10:1 (Gámiz et al., 2010). The LOD and LOQ were $0.01 \mathrm{mg} \mathrm{L}^{-1}$ and $0.03 \mathrm{mg} \mathrm{L}^{-1}$, respectively.

\section{RESULTS AND DISCUSSION}

\section{Soil characterization}

Relevant physicochemical characteristics of the soils used in this study are given in Table 1. The soils had similar $\mathrm{pH}(7.0-7.4)$ and low organic carbon contents (0.62-1.10\%), the latter being a typical characteristic of soils from Mediterranean regions. The carbonate content was high for soil 1, moderate for soil 3, and low for soils 2 and 4. The cation exchange capacity (CEC) ranged from 15 to $42 \mathrm{cmol}_{\mathrm{C}} \mathrm{kg}^{-1}$ and was found to be highly correlated with the clay content of the soils ( $r=0.996, P<0.01)$.

Figure 2 shows the pore-size distribution of the soils in the range from 40 to $0.004 \mu \mathrm{m}$, determined by mercury intrusion porosimetry. Bars indicate the contribution of the corresponding pore-radius interval to the cumulative volume. In agreement with previous work, the mercury pore-size distributions were closely related to soil texture (Cox et al., 1994; Chung and Alexander, 1999; Aichberger et al., 2006). Pores with radii larger than $10 \mu \mathrm{m}$ predominated in soils 2 and 3, thus reflecting the coarse texture of these soils (Table 1). In contrast, medium- to small-sized pores predominated in soils 1 and 4 (Figure 2). These pores probably resulted from aggregation of fine silt and clay particles, which clearly predominated in soils 1 and 4 (Table 1 ).

The X-ray diffraction patterns of oriented specimens of $\mathrm{Mg}^{2+}$ - and $\mathrm{K}^{+}$-saturated soil clay (< $2 \mu \mathrm{m}$ ) fractions are given in Figure 3. The X-ray diffractograms revealed that phyllosilicates dominated the soil clay fractions. The absence of any diffraction peak near $14 \AA$ in the Mg- 
saturated samples solvated with ethylene glycol (Mg-EG) and in the K-saturated samples calcined at $550^{\circ} \mathrm{C}\left(\mathrm{K}-550^{\circ} \mathrm{C}\right)$ indicated absence of chlorite in the soil clay samples (White and Dixon, 2003; Calvaruso et al., 2009). Consequently, the diffractions at $17 \AA, 10 \AA$, and $7 \AA$ in the Mg-EG diffractograms (Figure 3) were attributed to the (001) reflections of smectite-, illite- (or mica-), and kaolinite-type phyllosilicates, respectively. The additional diffractions at $5.00 \AA\left(\sim 18^{\circ} 2 \Theta\right)$ and $3.33 \AA\left(\sim 27^{\circ} 2 \Theta\right)$ were attributed to the (002) and (003) illite reflections, whereas that at $3.57 \AA\left(\sim 25^{\circ} 2 \Theta\right)$ was attributed to the (002) kaolinite reflection. It should be noted that although the (101) reflection of quartz could have contributed to the diffraction peak at $3.33 \AA$, the very low intensity of the (100) quartz reflection at $4.26 \AA$ ( 21 ${ }^{\circ} 2 \Theta$ ) observed in all diffractograms indicated low amounts of quartz in the soil clay samples. The contents in smectite, illite and kaolinite of the soil clay fractions (Table 2) were semiquantitatively estimated from the areas of the $17 \AA$, $10 \AA$, and $7 \AA$ diffraction peaks once normalized to the corresponding intensity factors of oriented specimens of the EG-solvated minerals, which were assumed to be 2 for smectite, 0.5 for illite and 1 for kaolinite (Galán and Espinosa, 1974). It was assumed that these phyllosilicates contributed to $100 \%$ of the clay fraction of the soils (Kahle et al., 2002). This assumption was based on the lack of significant diffraction peaks corresponding to other crystalline phases in the diffractograms (Figure 3) and the low content of the soils in relevant amorphous materials, such as organic matter and amorphous metal oxides. In this regard, oxalate-extraction indicated that amorphous Fe and $\mathrm{Al}$ accounted for less than $2 \%$ of the soil clay fractions.

The phyllosilicate content in the whole soils, also included in Table 2, was calculated from the composition of the soil clay fractions and the clay content of each soil. Despite smectites predominating in the clay fractions of soils 2 and 3, a low clay content resulted in moderate to low smectite contents in the whole soils. In the case of the clay soils, soil 1 contained $17 \%$ smectitic minerals, whereas the absence of any diffraction peak at $17 \AA$ in the Mg-EG 
diffractogram indicated lack of smectites in soil 4 . Thus, the different clay contents and mineralogy of the soils resulted in a range of smectite contents, which decreased in the following order: soil $1(17 \%)>$ soil $2(10 \%)>$ soil $3(3 \%)>$ soil $4(0 \%)$.

\section{Effect of spermine on fluometuron sorption by the soils}

Figure 4 shows the percentage of fluometuron sorbed by the soils at a single herbicide concentration of $1 \mathrm{mg} \mathrm{L}^{-1}$ either in the absence of spermine or in the presence of an amount of spermine equal to the CEC of each soil. The corresponding sorption distribution coefficients, $K_{\mathrm{d}}\left(=C_{\mathrm{s}} / C_{\mathrm{e}}\right)$, are summarized in Table 3 . In the absence of spermine, fluometuron sorption by soils 1 and 4 was considerably greater than that by soils 2 and 3, most likely as a result of their greater clay and organic C contents (Table 1). Predominance of small-sized pores (Figure 2) could have also contributed to enhance the herbicide sorption process in soils 1 and 4 (Cox et al., 1994). Upon spermine addition, a great increase in fluometuron sorption was observed for the clay soil rich in smectites (soil 1), whereas this effect was very small for the clay soil lacking smectites (soil 4) and also for the loamy sand soil (soil 3), with very low smectite content (Figure 4, Table 3). The sandy loam soil (soil 2), with moderate smectite content, had an intermediate behavior. The increase in fluometuron sorption upon spermine addition was thus clearly related to the smectite content of the soils, decreasing in the following order: soil $1>$ soil $2>$ soil $3 \approx$ soil 4 (Figure 4 , Table 3 ).

Previous work has shown that modification of reference smectites with spermine cations leads to interlayer organoclay complexes with selective affinities for phenylurea herbicides such as diuron and fluometuron (Celis et al., 2007; Gámiz et al., 2010). It appears that the sorption mechanism may involve (i) hydrogen bonding between the $\mathrm{C}=\mathrm{O}$ group of the herbicide and the $-\mathrm{NH}_{3}{ }^{+} /-\mathrm{NH}_{2}{ }^{+}$- groups of spermine and (ii) hydrophobic interactions between the herbicide and the alkyl chains of spermine (Celis et al., 2007). The surface charge density 
of the clay mineral and the amount of intercalated spermine appeared to be important factors determining the sorption of diuron and fluometuron by spermine-modified reference smectites, mainly because such variables determine the space available for herbicide sorption within the organoclay structure (Jaynes and Boyd, 1991; Celis et al., 2007, Gámiz et al., 2010). The results reported in Figure 4 and Table 3 show that the presence of spermine enhanced fluometuron sorption also in natural soils, and strongly indicate that this effect was directly related to the presence of expandable (smectitic) clay minerals. As an example, the distribution coefficient, $K_{\mathrm{d}}$, for fluometuron sorption on soil 1 (containing $17 \%$ smectites) increased by a factor of 7.6 by the presence of spermine, whereas an increase in the $K_{\mathrm{d}}$ value as small as $10 \%$ was measured for soils 3 and 4 , which contained less than $5 \%$ smectites (Table 2). This small increase in the $K_{\mathrm{d}}$ value measured for soils 3 and 4 could be attributed to the small amount of smectites present in soil 3 or the presence of some active illitic minerals in soil 4 (Table 2).

Fluometuron sorption as a function of the amount of spermine added to soil 1 was also determined and the results reported in Figure 5. Fluometuron sorption by soil 1 steadily increased with the amount of spermine added up to an amount of spermine corresponding to $25 \%$ of the CEC of the soil. Further addition of spermine did not result in additional sorption of fluometuron. Previous work has shown that increasing the amount of organic cation up to the CEC of clay minerals increases the hydrophobicity of the clay mineral surface, but a maximum transformation from hydrophilic to hydrophobic does not always result in a maximum sorption of hydrophobic organic compounds (Carrizosa et al., 2000; Nir et al., 2000; El-Nahhal et al., 1998, 2001; Cruz-Guzmán et al., 2004; Cornejo et al., 2008). Clogging of the interlayer space as a result of large organic cation loadings can give structures which preclude access to the sorption sites (Nir et al., 2000; Cornejo et al., 2008). A similar phenomenon may have operated in soil 1 , since the amount of fluometuron sorbed on soil 
treated with spermine cations at a loading of $25 \%$ of the soil CEC was similar to that on soil treated with spermine at a loading up to the CEC (Figure 5). In addition, the possibility exists that not all the cation exchange sites in soil were accessible for spermine cations or that spermine interaction with soil components different from smectites, such as metal oxides or organic matter, produced no effect on fluometuron sorption.

\section{Leaching and persistence experiments}

Soils 1 and 4 were selected for leaching experiments because, having similar clay textures, their responses to spermine addition with regard to fluometuron sorption were markedly different, as a result of their different smectite contents (Figure 4, Table 3). For the untreated soils, fluometuron concentrations in leachates of soil 4 were considerably greater than those measured in leachates of soil 1 , but the maximum concentration of fluometuron appeared at $195 \mathrm{~mL}$ of water added (3.1 pore volumes) for both soils (Figure 6). This result was in accordance with the expected retention factors $(R F)$ for fluometuron in soils 1 and 4 , calculated using Eq. 1, which were 2.9 (183 mL water added) for soil 1 and 3.2 (202 mL water added) for soil 4 (Table 3). Thus, linear, instantaneous, and reversible sorption conditions described well the movement of fluometuron in the soil columns.

For untreated soils, fluometuron BTCs also revealed a marked difference in the individual leachate concentrations and in turn in the total amount of herbicide leached from soils 1 and 4 . Most fluometuron (> 90\%) added to soil 4 was recovered in leachates, whereas the total amount of herbicide leached from soil 1 accounted for only $25 \%$ of the herbicide applied to the soil column (Figure 6). The amount of herbicide extracted from soil 1 at the end of the column leaching experiment was less than 5\% of the amount applied, so that the fluometuron not recovered is likely to correspond to the degradation of the herbicide within the soil column and/or the formation of strongly bound herbicide residues. Taking into account that soil 1 had 
received repeated applications of fluometuron for years as an agronomic practice for weed control, we believe that the small amount of herbicide leached is likely to be due to rapid degradation of fluometuron in this soil by adapted soil microorganisms (Cox et al., 1996).

When spermine was coapplied with fluometuron, herbicide leaching was retarded in soil 1, whereas the effect was negligible in soil 4 (Figure 6). This result can be related to the distinct effect of spermine on the sorption of fluometuron by soils 1 and 4 (Table 3). The position of the maximum concentration peak in the BTC of fluometuron in soil 1 in the presence of spermine was centered at about $250 \mathrm{~mL}$ of water added ( 4.0 pore volumes). This value is close to the value of $275 \mathrm{~mL}(R F=4.4)$ predicted by assuming that spermine interacted with the top 0-2.5 cm soil increasing the $K_{\mathrm{d}}$ value of soil 1 from 0.74 to $5.60 \mathrm{~L} \mathrm{~kg}^{-1}$ (Table 3). A similar calculation for soil 4 predicted a negligible effect of spermine on the fluometuron $R F$ value (Table 3).

An additional effect of spermine addition to soil 1 was the increase in the total amount of fluometuron leached from $25 \%$ to $52 \%$ of the amount of herbicide applied to the soil column. This indicated the persistence of the herbicide could have been increased upon spermine coapplication. A soil incubation experiment confirmed longer persistence of fluometuron in soil 1 treated with spermine compared to the untreated soil (Figure 7). The dissipation of fluometuron in spermine-free soil 1 was rapid and the sigmoidal shape of the dissipation curve is typical of the degradation of compounds used as the microbial growth substrate (Gámiz et al., 2010). In the presence of spermine, the dissipation of fluometuron in soil 1 was significantly retarded. Although the enhanced sorption could have protected the herbicide from degradation and/or formation of strongly-bound residues in soil, previous work has indicated that sorption of phenylurea herbicides on spermine-exchanged reference smectites is a reversible process and does not seem to reduce the bioavailability of the herbicide to soil microorganisms (Trigo et al., 2009; Gámiz et al., 2010). Alternatively, spermine cations could 
have acted as a readily available carbon and nitrogen source for such bacteria, retarding the degradation of the herbicide. Independent of the cause for the enhanced persistence of the herbicide, our results show that coapplication of spermine could be useful to prolong the persistence of fluometuron in soils where the herbicide is rapidly degraded, for instance due to previous repeated herbicide applications.

\section{CONCLUSIONS}

The reaction of organic cations with soil smectites can be useful as a strategy to control pesticide mobility and persistence in soils. The results of this work show that the presence of spermine enhances fluometuron sorption in smectite-containing soils, most likely because reaction between spermine cations and soil smectites forms "in situ" organoclay complexes with high affinity for the herbicide. Sorption experiments with four different soils revealed that the effect of spermine on fluometuron sorption depended on the smectite content of the soil and on the amount of spermine added. The increase in fluometuron sorption by spermine addition to a soil rich in smectites retarded the leaching of the herbicide through soil columns and, interestingly, also prolonged its soil persistence, whereas these effects were negligible for a soil lacking smectites. Therefore, the simultaneous application of fluometuron and spermine could be useful to enhance the herbicide retention process in soil, and to prolong the persistence of the herbicide in scenarios where its rapid degradation could result in loss of herbicidal efficacy. Additional research would be needed to verify adequate weed control of the herbicide under simultaneous application with spermine and to assess potential sideeffects of spermine on target and non-target organisms. 


\section{REFERENCES}

Aichberger, H., A.P. Loibner, R. Celis, R. Braun, F. Ottner, and H. Rost. 2006. Assessment of factors governing biodegradability of PAHs in three soils aged under field conditions. Soil Sediment Contam. 15:73-85.

Albarrán, A., R. Celis, M.C. Hermosín, A. López-Piñeiro, J.J. Ortega-Calvo, and J. Cornejo. 2003. Effects of solid olive-mill waste addition to soil on sorption, degradation and leaching of the herbicide simazine. Soil Use Manag. 19:150-156.

Boyd, S.A., J.F. Lee, and M.M. Mortland. 1988. Attenuating organic contaminant mobility by soil modification. Nature (London) 333:345-347.

Brixie, J.M., and S.A. Boyd. 1994. Treatment of contaminated soils with organoclays to reduce leachable pentachlorophenol. J. Environ. Qual. 23:1283-1290.

Brown, G. 1961. The X-ray identification and crystal structures of clay minerals. Mineralogical Society, London.

Calvaruso, C., L. Mareschal, M.P. Turpault, and E. Leclerc. 2009. Rapid clay weathering in the rhizosphere of Norway spruce and oak in an acid forest ecosystem. Soil Sci. Soc. Am. J. 73:331-338.

Carrizosa, M.J., M.J. Calderón, M.C. Hermosín, and J. Cornejo. 2000. Organosmectites as sorbent and carrier of the herbicide bentazone. Sci. Total Environ. 247:285-293. 
Celis, R., C. Trigo, G. Facenda, M.C. Hermosín, and J. Cornejo. 2007. Selective modification

402

403

404

405

406

407

408

409

410

411

412

413

414

415

416

417

418

419

420

421

422

423

424

of clay minerals for the adsorption of herbicides widely used in olive groves. J. Agric. Food Chem. 55:6650-6658.

Chung, N., and M. Alexander. 1999. Relationship between nanoporosity and other properties of soil. Soil Sci. 164:726-730.

Cornejo, J., R. Celis, I. Pavlovic, and M.A. Ulibarri. 2008. Interactions of pesticides with clays and layered double hydroxides: a review. Clay Miner. 43:155-175.

Cox, L., R. Celis, M.C. Hermosín, and J. Cornejo. 1994. Leaching patterns of pesticides as related to sorption and porosity properties of soils. pp. 1325-1330, In: Proceedings of the BCPC Conference on Pests and Diseases, Vol. 3, BCPC, Brighton, U.K.

Cox, L., A. Walker, and S.J. Welch. 1996. Evidence for accelerated degradation of isoproturon in soils. Pestic. Sci. 48:253-260.

Cruz-Guzmán, M., R. Celis, M.C. Hermosín, and J. Cornejo. 2004. Adsorption of the herbicide simazine by montmorillonite modified with natural organic cations. Environ. Sci. Technol. 38:180-186.

El-Nahhal, Y., S. Nir, T. Polubesova, L. Margulies, and B. Rubin. 1998. Leaching, phytotoxicity, and weed control of new formulations of alachlor. J. Agric. Food Chem. 46:3305-3313. 
El-Nahhal, Y., S. Nir, C. Serban, O. Rabinovitz, and B. Rubin. 2001. Organo-clay formulation of acetochlor for reduced movement in soil. J. Agric. Food Chem. 49:5364-5371.

Flores-Céspedes, F., E. González-Pradas, M. Fernández-Pérez, and M. Villafranca-Sánchez. 2002. Effects of dissolved organic carbon on sorption and mobility of imidacloprid in soil. J. Environ. Qual. 31:880-888. Manag. Sci. 59:681-690. magnetic resonance as a tool for determining protonation constants of natural polyprotic bases in solution. Anal. Biochem. 231:374-382.

Galán, E., and J. Espinosa. 1974. El caolín en España: características, identificación y ensayos cerámicos. Sociedad Española de Cerámica y Vidrio, Madrid.

Gámiz, B., R. Celis, M.C. Hermosín, and J. Cornejo. 2010. Organoclays as soil amendments to increase the efficacy and reduce the environmental impact of the herbicide fluometuron in agricultural soils. J. Agric. Food Chem. 58:7893-7901.

Hapeman, C.J., L.L. McConnell, C.P. Rice, A.M. Sadeghi, W.F. Schmidt, G.W. McCarty, J.L. Starr, P.J. Rice, J.T. Angier, and J.A. Harman-Fetcho. 2003. Current United States Department of Agriculture-Agricultural Research Service research on understanding agrochemical fate and transport to prevent and mitigate adverse environmental impacts. Pest 
Hermosín, M.C., M.A. Ulibarri, M. Mansour, and J. Cornejo. 1992. Assaying sorbents for 2,4dichlorophenoxyacetic acid from water. Fres. Environ. Bull. 1: 472-481.

Jackson, M.L. 1975. Soil chemical analysis. 2nd edition. University of Wisconsin, Madison, WI.

Jaynes, W.F., and S.A. Boyd. 1991. Clay mineral type and organic compound sorption by hexadecyltrimethylammonium-exchanged clays. Soil Sci. Soc. Am. J. 55:43-48.

Kahle, M., M. Kleber, and R. Jahn. 2002. Review of XRD-based quantitative analyses of clay minerals in soils: the suitability of mineral intensity factors. Geoderma 109:191-205.

Klute, A. 1986. Methods of soil analysis. Part 1. Physical and mineralogical methods. 2nd edition. SSSA Book Series No 5, Madison, WI.

Lee, J.-F., J.R. Crum, and S.A. Boyd. 1989. Enhanced retention of organic contaminants by soils exchanged with organic cations. Environ. Sci. Technol. 23:1365-1372.

Locke, M.A., M.A. Weaver, R.M. Zablotowicz, R.W. Steinriede, C.T. Bryson, and R.F. Cullum. 2011. Constructed wetlands as a component of the agricultural landscape: mitigation of herbicides in simulated runoff from upland drainage areas. Chemosphere 83:1532-1538.

McKeague, J.A., and J.H. Day. 1966. Dithionite- and oxalate-extractable Fe and $\mathrm{Al}$ as aids in differentiating various classes of soils. Can. J. Soil Sci. 46:13-22. 
Mueller, T.C., T.B. Moorman, and C.E. Snipes. 1992. Effect of concentration, sorption, and microbial biomass on degradation of the herbicide fluometuron in surface and subsurface soils. J. Agric. Food Chem. 40:4517-2522.

Nir, S., T. Undabeytia, D. Yaron-Marcovich, Y. El-Nahhal, T. Polubesova, C. Serban, G. Rytwo, G. Lagaly, and B. Rubin B. 2000. Optimization of adsorption of hydrophobic herbicides on montmorillonite preadsorbed by monovalent organic cations: interaction between phenyl rings. Environ. Sci. Technol. 34:1269-1274.

Prost, R., and B. Yaron. 2001. Use of modified clays for controlling soil environmental quality. Soil Sci. 166:880-895.

Rankins Jr., A., D.R. Shaw, and W.L. Kingery. 2002. Comparison of fluometuron sorption to soil from a filter strip and cropped field. Weed Sci. 50:820-823.

Rao, P.S.C., A.G. Hornsby, and R.E. Jessup. 1985. Indices for ranking the potential for pesticide contamination of groundwater. Proc. Soil Crop Sci. Fla. 44:1-8.

Rodríguez-Cruz, M.S., M.J. Sánchez-Martín, M.J. Andrades, and M. Sánchez-Camazano. 2007. Retention of pesticides in soil columns modified in situ with a cationic surfactant. Sci. Total Environ. 378:104-108.

Sánchez, L., E. Romero, F. Sánchez-Rasero, G. Dios, and A. Peña. 2003. Enhanced soil sorption of methidathion using sewage sludge and surfactants. Pest Manag. Sci. 59:857-864. 
500

501

502

503

504

505

506

507

508

509

510

511

512

513

514

515

516

517

518

519

520

521

522

523

Savage, K.E., and R.D. Wauchope. 1974. Fluometuron adsorption-desorption equilibria in soil. Weed Sci. 22:106-110.

Sparks, D.L. 1996. Methods of soil analysis. Part 3. Chemical methods. SSSA Book Series N ${ }^{\circ}$ 5, Madison, WI.

Trigo, C., R. Celis, M.C. Hermosín, and J. Cornejo. 2009. Organoclay-based formulations to reduce the environmental impact of the herbicide diuron in olive groves. Soil Sci. Soc. Am. J. 73:1652-1657.

Undabeytia, T., F. Sopeña, T. Sánchez-Verdejo, J. Villaverde, S. Nir, E. Morillo, and C. Maqueda. 2010. Performance of slow-release formulations of alachlor. Soil Sci. Soc. Am. J. 74:898-905.

Washburn, E.W. 1921. Note on a method of determining the distribution of pore sizes in a porous material. Proc. Nat. Acad. Sci. USA 7:115-116.

White, G.N., and J.B. Dixon. 2003. Soil mineralogy laboratory manual, 9th edition, Department of Soil and Crop Sciences, Texas A\&M University, College Station, Texas.

Worthing, C.R., and R.J. Hance. 1991. The pesticide manual. British Crop Protection Council, Surey, U.K. 


\section{LEGENDS FOR FIGURES}

526

Figure 1. Molecular structures of fluometuron and spermine.

528

Figure 2. Relative (bars) and cumulative (curves) pore-size distributions of the soils determined by mercury intrusion porosimetry. Error bars correspond to the standard error of triplicate measurements.

Figure 3. X-ray diffractograms of oriented specimens of soil clay fractions: $\mathrm{Mg}^{2+}$-saturated (Mg), $\mathrm{Mg}^{2+}$-saturated followed by solvation with ethylene glycol (Mg-EG), $\mathrm{K}^{+}$-saturated (K), and $\mathrm{K}^{+}$-saturated, then calcined at $550^{\circ} \mathrm{C}\left(\mathrm{K}-550^{\circ} \mathrm{C}\right)$.

Figure 4. Percentages of fluometuron sorbed by the soils in the absence of spermine and in the presence of an amount of spermine equal to the CEC of each soil. The experiment was conducted at an initial fluometuron concentration $1 \mathrm{mg} \mathrm{L}^{-1}$ and a soil:solution ratio $4 \mathrm{~g}: 8 \mathrm{~mL}$.

Figure 5. Percentages of fluometuron sorbed by soil 1 in the presence of an amount of spermine equal to $0,1,5,10,25$, and $100 \%$ of the CEC of the soil. The experiment was conducted at an initial fluometuron concentration $1 \mathrm{mg} \mathrm{L}^{-1}$ and a soil:solution ratio $4 \mathrm{~g}: 8 \mathrm{~mL}$.

Figure 6. Relative and cumulative breakthrough curves (BTCs) of fluometuron in soils 1 and 4 in the absence and in the presence of spermine.

Figure 7. Dissipation curves of fluometuron in soil 1 in the absence and in the presence of spermine. 
Table 1. Physicochemical characteristics of the soils used.

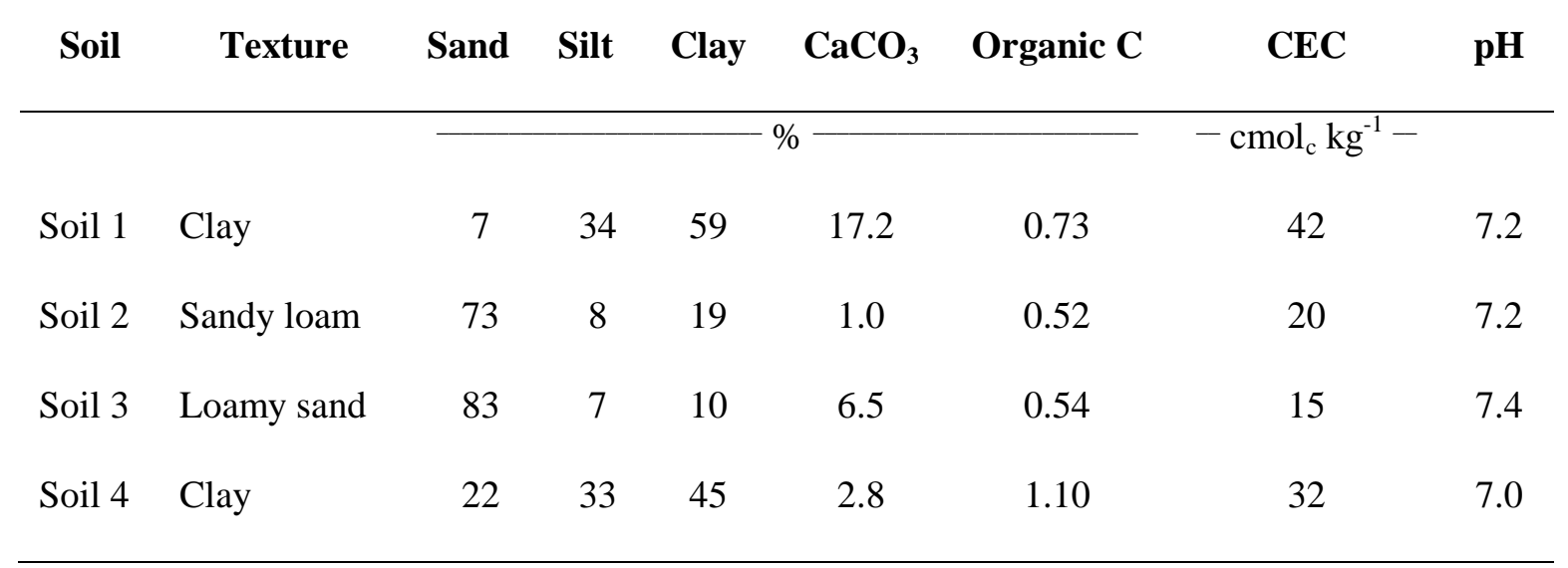


Table 2. Smectite, illite and kaolinite contents of the soil clay fractions and the whole soils.

$$
\text { Soil clay }(<2 \mu \mathrm{m}) \text { fraction Whole soil }
$$

\begin{tabular}{|c|c|c|c|c|c|c|}
\hline Soil & Smectite & Illite & Kaolinite & Smectite & Illite & Kaolinite \\
\hline & \multicolumn{3}{|c|}{$\longrightarrow \%$} & $\longrightarrow$ & $-\%$ & \\
\hline Soil 1 & 28 & 57 & 15 & 17 & 34 & 9 \\
\hline Soil 2 & 52 & 19 & 29 & 10 & 4 & 6 \\
\hline Soil 3 & 34 & 46 & 20 & 3 & 5 & 2 \\
\hline Soil 4 & 0 & 88 & 12 & 0 & 40 & 5 \\
\hline
\end{tabular}


Table 3. Distribution coefficients, $K_{d}$, for fluometuron sorption on untreated and spermine-treated soils and predicted retardation factors $(R F)$ for fluometuron leaching through soil columns calculated assuming linear, instantaneous, and reversible sorption conditions (Eq. 1).

Untreated soil Spermine-treated soil

$\begin{array}{lllll}\text { Soil } & K_{\mathrm{d}} & \boldsymbol{R} F & \boldsymbol{K}_{\mathrm{d}}^{\dagger}\end{array}$

\begin{tabular}{lcccc}
\hline & $\mathrm{L} \mathrm{kg}^{-1}-$ & & \\
Soil 1 & $0.74 \pm 0.01^{\S}$ & 2.9 & $5.60 \pm 0.20$ & 4.4 \\
Soil 2 & $0.39 \pm 0.02$ & 2.0 & $0.69 \pm 0.03$ & 2.1 \\
Soil 3 & $0.36 \pm 0.01$ & 1.9 & $0.39 \pm 0.01$ & 1.9 \\
Soil 4 & $0.87 \pm 0.02$ & 3.2 & $0.96 \pm 0.02$ & 3.2 \\
\hline
\end{tabular}

${ }^{\dagger} K_{\mathrm{d}}$ values for soils treated with an amount of spermine equal to their CEC.

${ }^{\ddagger}$ It was assumed that the spermine added reacted with the top $0-2.5 \mathrm{~cm}$ of the soil column.

${ }^{\S}$ Mean \pm standard error. 


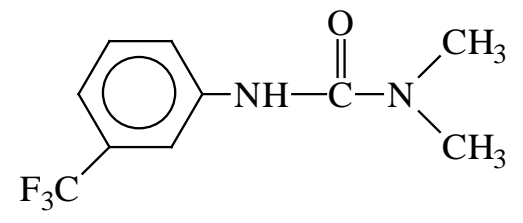

Fluometuron

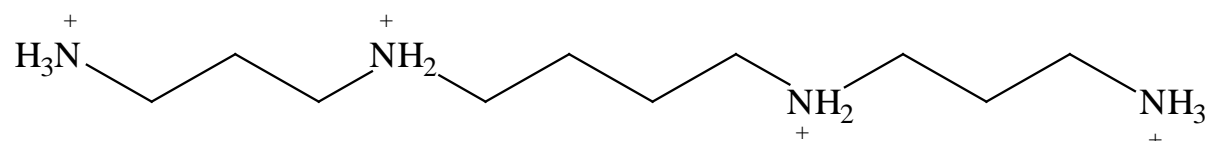

Spermine

Figure 1. Molecular structures of fluometuron and spermine. 

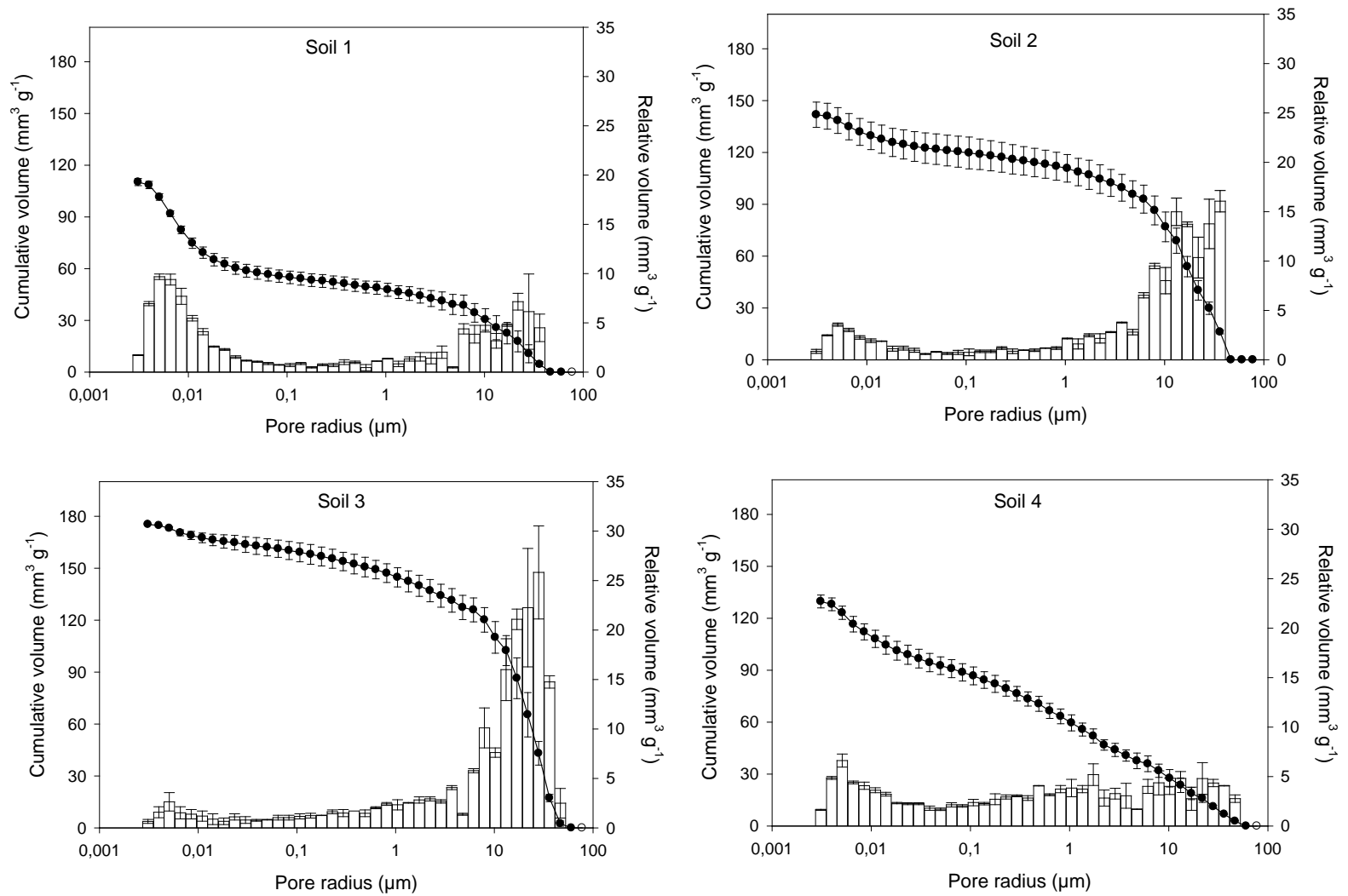

Figure 2. Relative (bars) and cumulative (curves) pore-size distributions of the soils determined by mercury intrusion porosimetry. Error bars correspond to the standard error of triplicate measurements. 

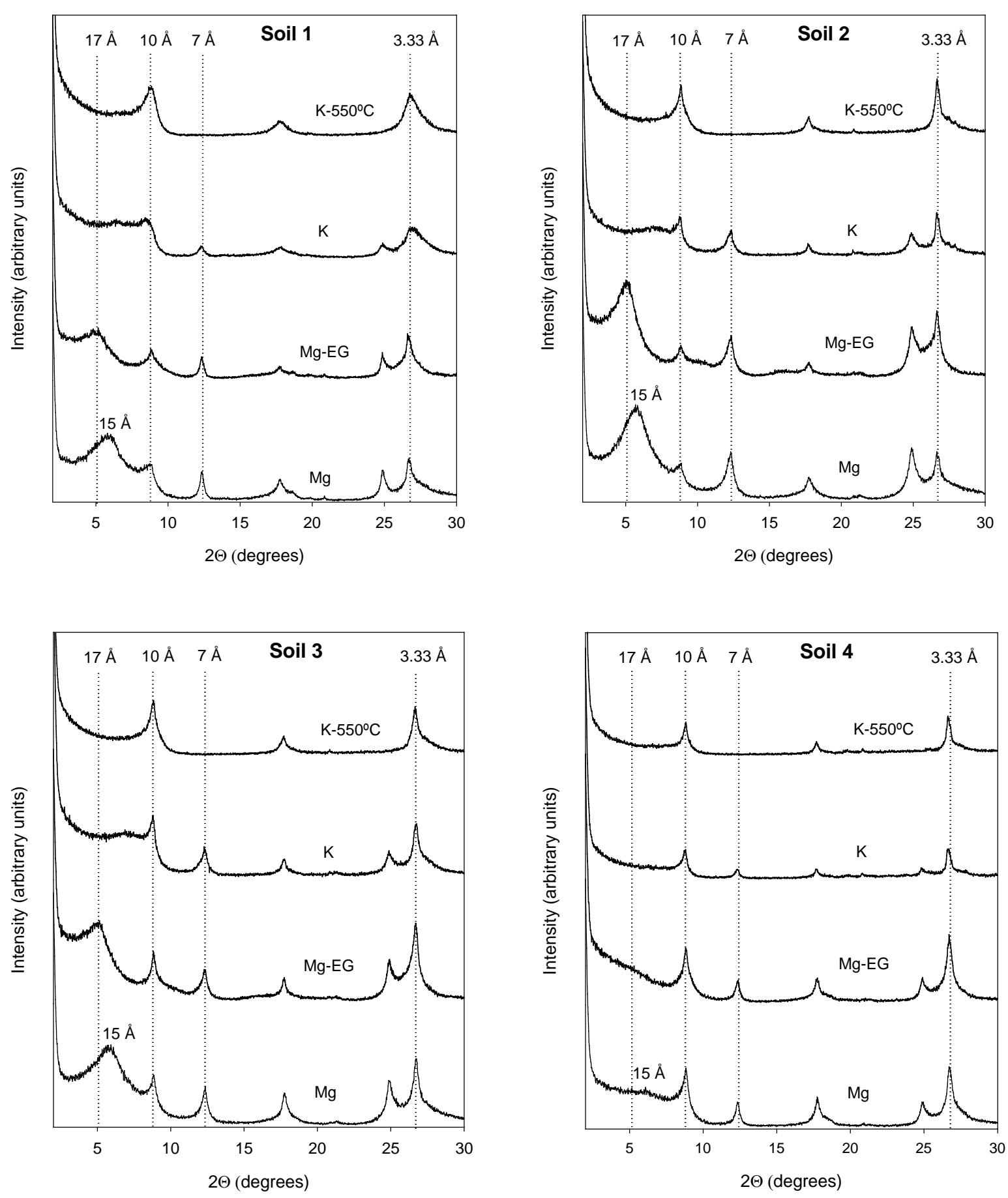

Figure 3. X-ray diffractograms of oriented specimens of soil clay fractions: $\mathbf{M g}^{2+}$ saturated (Mg), $\mathrm{Mg}^{2+}$-saturated followed by solvation with ethylene glycol (Mg-EG), $\mathrm{K}^{+}$saturated $(\mathrm{K})$, and $\mathrm{K}^{+}$-saturated, then calcined at $550^{\circ} \mathrm{C}\left(\mathrm{K}-550^{\circ} \mathrm{C}\right)$. 


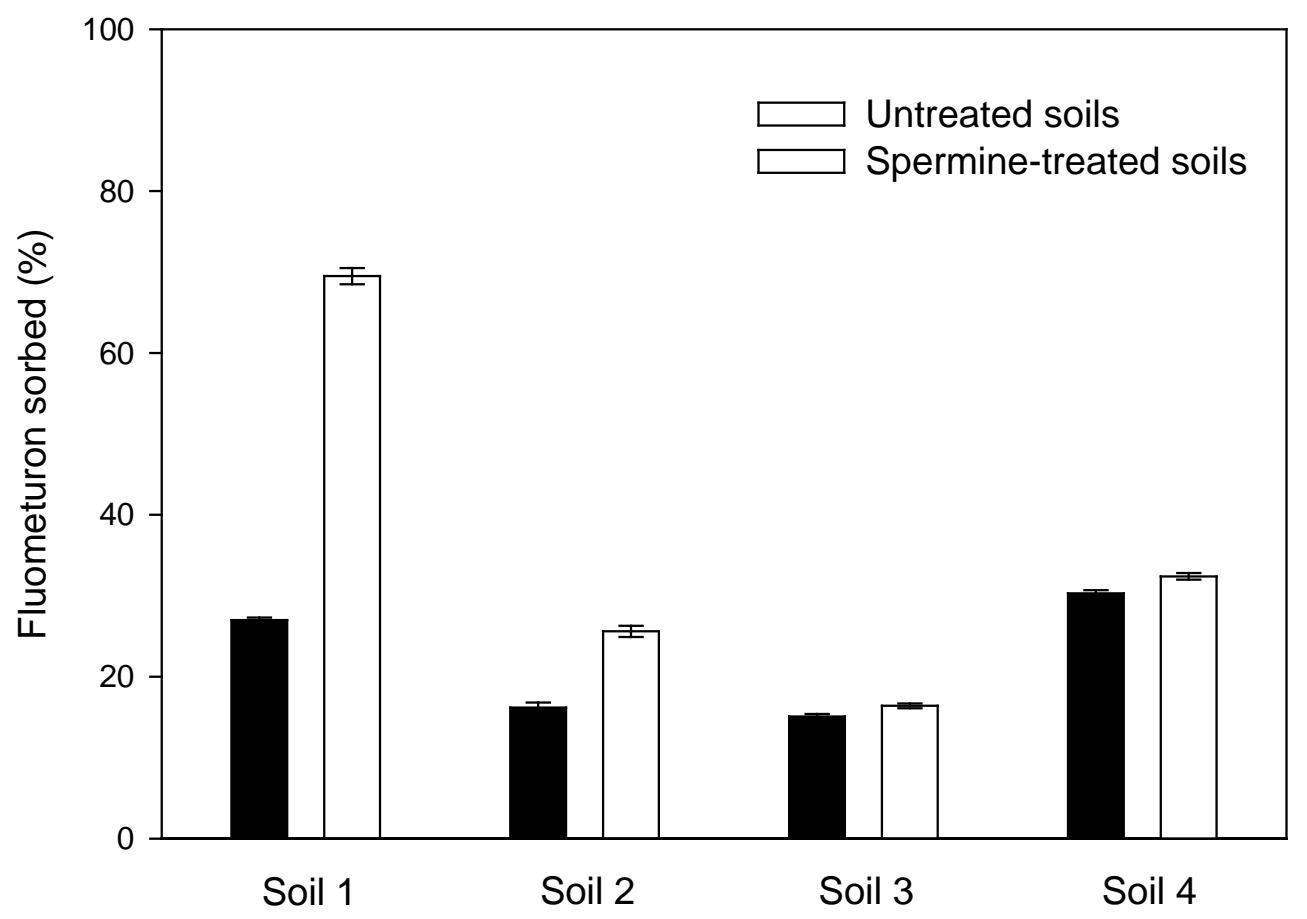

Figure 4. Percentages of fluometuron sorbed by the soils in the absence of spermine and in the presence of an amount of spermine equal to the CEC of each soil. The experiment was conducted at an initial fluometuron concentration $1 \mathrm{mg} \mathrm{L}^{-1}$ and a soil:solution ratio $4 \mathrm{g:8} \mathrm{mL}$. 


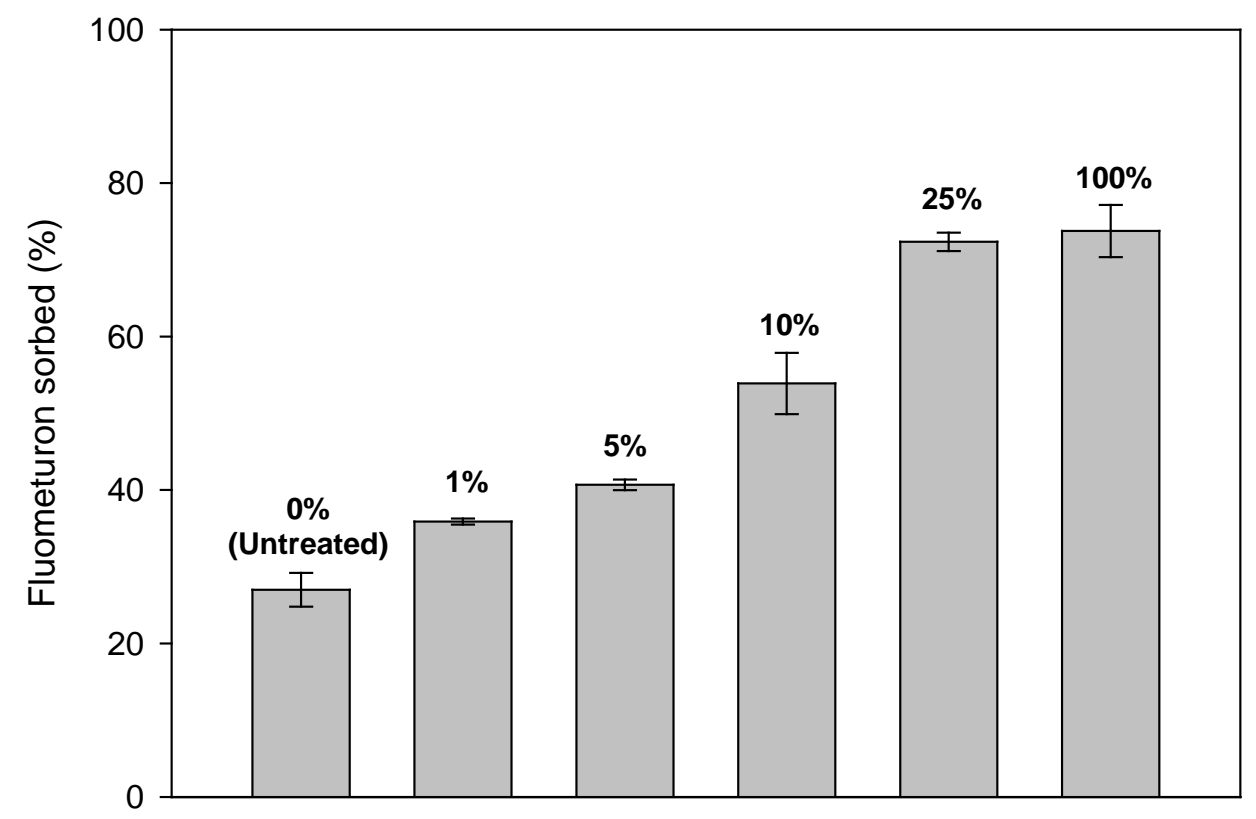

Figure 5. Percentages of fluometuron sorbed by soil 1 in the presence of an amount of spermine equal to $0,1,5,10,25$, and $100 \%$ of the CEC of the soil. The experiment was conducted at an initial fluometuron concentration $1 \mathrm{mg} \mathrm{L}^{-1}$ and a soil:solution ratio $4 \mathrm{g:8}$ mL. 

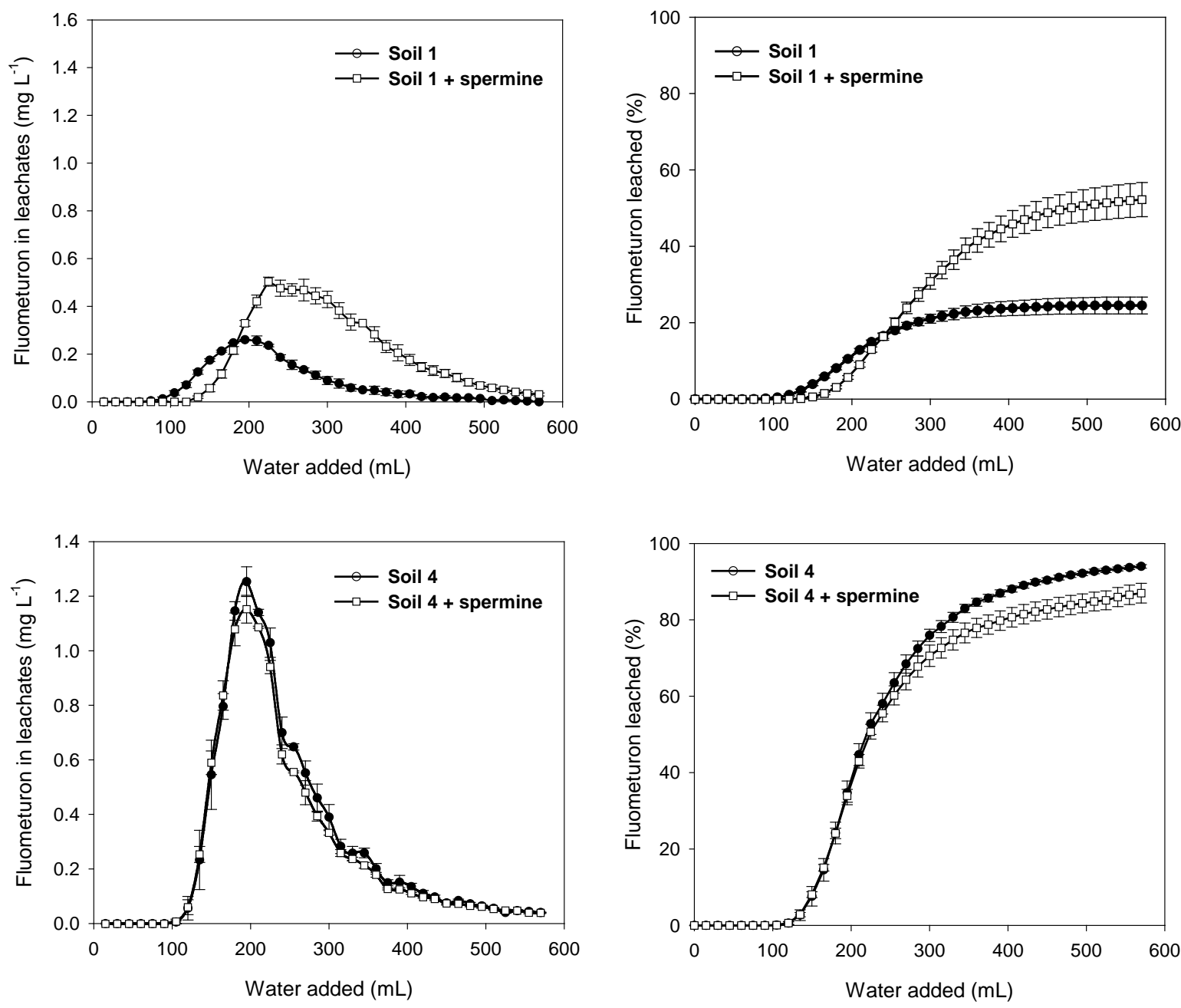

Figure 6. Relative and cumulative breakthrough curves (BTCs) of fluometuron in soils 1 and 4 in the absence and in the presence of spermine. 


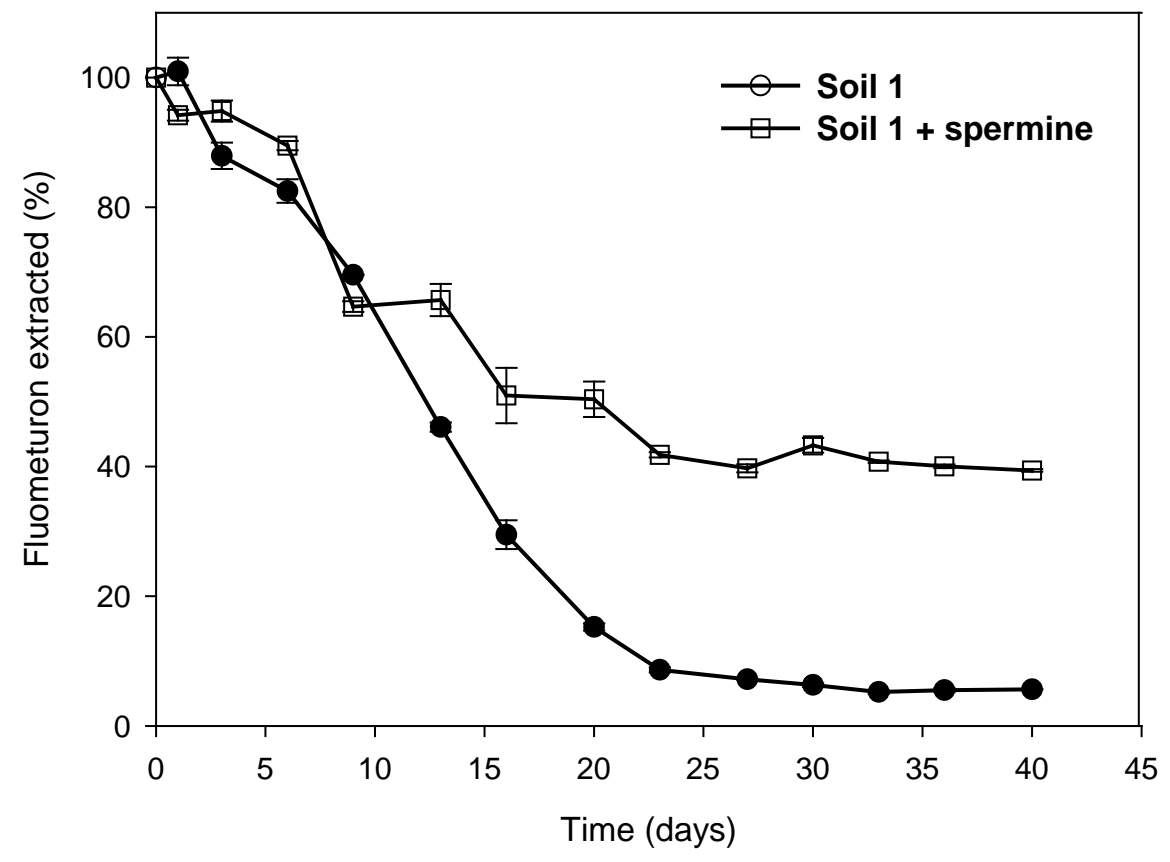

Figure 7. Dissipation curves of fluometuron in soil 1 in the absence and in the presence and of spermine. 